Науковий вісник Дьвівського націонадьного університету ветеринарної медицини та біотехнологій імені С.З. Гжицького

\author{
Scientific Messenger of Lviv National University \\ of Veterinary Medicine and Biotechnologies
}

\title{
Productive qualities of ducklings with different normalization methods trace elements in the diet
}

\author{
I.I. Ibatullin, M.I. Holubiev, V.V. Otchenashko, K.I. Makhno
}

National University of Life and Environmental Sciences of Ukraine, Kyiv, Ukraine

Article info

Received 15.01.2018

Received in revised form 28.02.2018

Accepted 03.03.2018

National University of Life and Environmental Sciences of Ukraine, Heroiv Oborony str., 15 , Kyiv, 03041, Ukraine.

Tel.: $+38-097-673-45-00$

E-mail: i.ibatullin@nubip.edu.ua golubev.mon@gmail.com, otchenashko@nubip.edu.ua makhnokostia@gmail.com
Ibatullin, I.I., Holubiev, M.I., Otchenashko, V.V., \& Makhno, K.I. (2018). Productive qualities of ducklings with different normalization methods trace elements in the diet. Scientific Messenger of Lviv National University of Veterinary Medicine and Biotechnologies. 20(84), 54-59. doi: $10.15421 /$ nvlvet8410

In the article, results of researches on an establishment of an optimum source of Manganese, Zinc, Iron and Copper are resulted. Different source Manganese, Zinc, Iron and Copper was additionally added mixed fodder for ducklings grown for meat. Experimental studies conducted in terms of problem research laboratory of feed additives National University of Life and Environmental Sciences of Ukraine. Independent experiment was conducted with growing meat ducklings. We conducted a randomized block experiment with 5 treatments, each with 4 replicates of 25 growing ducks ( 1 to $42 \mathrm{~d}$ of age). A diet consisting of corn, soybean and sunflower meal, fish meal, premix $(22.5 \% \mathrm{CP}, 2.92 \mathrm{kcal}$ of $\mathrm{ME} / \mathrm{g}$ on 1 to $14 \mathrm{~d}$ of age, $18.5 \% \mathrm{CP}$, $2.90 \mathrm{kcal}$ of ME/g on 15 to $42 \mathrm{~d}$ of age) having severally Manganese, Zinc, Iron, Copper at sulphate, glycinate and citrate. The premix was formulated to contain the requirements of trace elements in combination of either inorganic (sulphate form) or organic form (glycinate and citrate form). Diets were supplemented with the organic form of zinc, copper, manganese or iron at the rate of $100 \%$ or $75 \%$ of the total requirements of the elements. Diets and water were offered ad libitum. After 6 weeks of dietary treatments the growth performance (feed intake, body weight, daily gain, feed conversion, homogeneity of the poultry) were affected by dietary treatments. Results indicated that chicks fed diets containing 100\% organic minerals (Mn, Zn, Fe, Cu) had significantly higher body weight, better feed conversion compared with those of inorganic control minerals treatment. Use of fodder for ducklings, which are grown for meat glycinate Mn, $\mathrm{Zn}, \mathrm{Fe}, \mathrm{Cu}$ versus sulfate improves their productive performance. The body weight of ducklings at $42 \mathrm{~d}$ of age is more by $1.6 \%(P<0.05)$ and the conversion of feed is $1.0 \%$ higher. The conversion of feed from consumption was rather high $\left(R^{2}=0.84\right)$, which confirms the change in the productive indicators of duckling from the feed factor.

Key words: duckling, body weight, feed, inorganic and organic sources of trace elements.

\section{Продуктивність молодняку качок за різних способів нормування мікроелементів у комбікормі}

\author{
I.І. Ібатуллін, М.І. Голубєв, В.В. Отченашко, К.І. Махно
}

Наџіональний університет біоресурсів і природокористування Украӥни, м. Київ, Украӥна

\footnotetext{
Наведено результати досліджень з встановлення оптимального джерела Мангану, Цинку, Феруму та Купруму, який додатково вводять у комбікорми для каченят, яких вирочують на м'ясо. Експериментальні дослідження проводились в умовах проблемної науково-дослідної лабораторії кормових добавок Національного університету біоресурсів і природокористування України. Було проведено науково-господарський дослід на молодняку качок м'ясного напряму продуктивності. Дослід проводився за методом груп. Птахи були поділені на 5 груп, кожна з яких складалася з 4 підгруп по 25 добових каченят кожна (каченят вирощували від 1 до 42 діб). Базові комбікорми, що складалися з кукурудзи, соєвої макухи, соняшникового шроту, рибного борошна, вапняку та преміксу (22,5\% СП, 2,92 ккал/г у віщі від 1 до 14 діб, 18,5\% СП, 2,90 ккал/2 у віџі від 15 до 42 доби), містили відповідно такі джерела Мангану, Цинку, Феруму та Купруму: сульфат, гліцинат та иитрат. Премікс був складений таким сином, ще комбікорм містив досліджувані мікроелементи або в неорганічній формі (сульфати) або в органічній (гліцинати та цитрати). Раціони містили у контрольній групі 100\%, а у дослідних 100\% та 75\% досліджуваних елементів від загальної потреби. Комбікорм та воду каченята
} 
отримували вволю. Після 6-тижневого вирощування було встановлено зміни у показниках росту залежно від досліджуваного фактору. Використання у комбікормі для каченят, яких вирощують на м'ясо глічинатів Mn, Zn, Fe, Cu порівняно з сульфатами сприяє покращенню їх продуктивних показників. Маса тіла таких каченят у 42-добовому вічі збільшується на 1,6\% (P < 0,05), а конверсія корму у продуктивність на 1,0\% ефективніша. Конверсія корму від споживання була досить високою ( $\left.R^{2}=0,84\right)$, що підтверджує зміну продуктивних показників каченят від кормового фактору.

Ключові слова: каченята, маса тіла, комбікорм, неорганічні і органічні джерела мікроелементів.

\section{Вступ}

Нині джерела мінеральних речовин для виробництва преміксів та комбікормів на ринку доступні у різноманітних формах, і періодично виникають проблеми у відсутності певних знань про їх хімічний склад, або ж стабільність цих солей. Тому ступінь чистоти мікроелементу в мінеральній речовині $є$ критичним критерієм при виборі цього джерела мікроелементу. Екологічним критерієм безпеки таких солей мікроелементів є можливість забруднення навколишнього середовища, в першу чергу, важкими металами. Ці метали та інші домішки можуть становити токсичну небезпеку для ефективного виробництва продукції птахівництва.

Потреба в есенційних мікроелементах досить часто покривається тією концентрацією, яка міститься у звичайних кормах. Однак, за рахунок використання рослинних ресурсів, які зібрані в різних біогеохімічних провінціях, раціони можуть містити нестачу певних мікроелементів, а зібрані рослини різнитися їх засвоюваністю. У зв'язку з розвитком інтенсивного птахівництва, домашні раціони для сільськогосподарської птиці потребують забезпечення адекватного постачання життєво необхідних мікроелементів.

Слід відмітити, що сільськогосподарська птиця сучасних кросів здатна до досить високої продуктивності, забезпечення якої потребує у свою чергу ретельного вивчення поживного профілю раціонів. Потреба різних видів сільськогосподарської птиці у мікроелементах, підбір солі мікроелементу та якість мінерального джерела - наразі це ділянки, які потребують уваги. Крім того, біологічна доступність неорганічних джерел мікроелементів обмежена природними факторами, тому актуально вивчати роль мікроелементів з різних органічних джерел для поліпшення доступності мінеральних комплексів у високопродуктивної птиці.

Мікроелементи (Манган, Цинк, Ферум та Купрум) знаходяться у невеликій кількості у раціонах сільськогосподарської птиці (до 100 мг/кг комбікорму). Однак, приймають участь у значній кількості травних та біосинтетичних процесів. Функціонуючи як каталізатори в ферментних системах, ці мікроелементи входять до складу сотень протеїнів, які залучені в проміжний обмін, секрецію гормонів, імунний захист тощо (NRC, 1994; Ibatullin et al., 2015; Wu, 2018).

Так, J. Yang та ін. (Yang et al., 2011) відзначають, що одночасне додавання Мангану, Цинку, Феруму та Купруму до раціону курчат не впливає на проліферацію лімфоцитів та відносну масу селезінки, однак при додатковому додаванні Цинку підвищується проліферація лімфоцитів. А у експерименті (Medvid et al., 2018) досліджено комплексний вплив композиції мікроелементів ( $\mathrm{Fe}, \mathrm{Cu}, \mathrm{Mn}, \mathrm{Co}, \mathrm{Zn})$ у формі наноак- вацитрату на гістоструктуру імунокомпетентних органів курчат-бройлерів. Вченими встановлено, що використання такої форми мікроелементів, за умови зниження абсолютної їх кількості на 10-50\%, забезпечує відповідний морфо-функціональний розвиток тимусу, клоакальної сумки та селезінки. Вплив різних рівнів комплексу цих мікроелементів у формі цитрату на неспецифічну і клітинну ланки імунітету у курчатбройлерів було досліджено на базі Інститут біології тварин НАAН (Medvid et al., 2017). Автор відмічає позитивний влив на формування і становлення факторів неспецифічної резистентності та клітинний імунітет в курчат-бройлерів у дозі, що відповідає 25-50\% від обгрунтованої кількості біоелементів у преміксі, що зумовлено кращою їх біологічною доступністю.

Bao Y.M. та ін. (Bao et al., 2007) досліджували різні рівні і джерела мікроелементів ( $\mathrm{Cu}, \mathrm{Fe}, \mathrm{Mn}, \mathrm{Zn})$ i дійшли висновку, що додавання 4 мг $\mathrm{Cu}$ та 40 мг кожного $3 \mathrm{Fe}, \mathrm{Mn}$ i $\mathrm{Zn} 3$ органічних джерел може бути адекватним рівнем для вирощування курчатбройлерів. Такої думки дотримуються у своїх публікаціях і A.G. Abdallah та ін. (Abdallah et al., 2009), однак відмічають, що курчата, які отримували у комбікормі 100\% від потреби органічних мікроелементів $(\mathrm{Zn}, \mathrm{Cu}, \mathrm{Mn}$ і $\mathrm{Fe})$, мають значно більшу масу тіла, кращу конверсію корму, вищий вміст сирої золи у великій стегновій кістці та сильніший імунітет порівняно 3 тими, які отримували нижчі рівні мікроелементів від потреби.

Sirri F. та ін. (Sirri et al., 2016) також вважають що заміна неорганічних джерел мікроелементів на органічні може мати потенційні переваги як і в підвищення продуктивності курчат так і у скороченні виділення цих мікроелементів у навколишнє середовище. Однак необхідні подальші дослідження для підтвердження таких даних та для детальнішого вивчення у потребі в мікроелементах сучасних кросів сільськогосподарської птиці.

Метою нашого дослідження було вивчення впливу мінеральних добавок Мангану, Цинку, Феруму та Купруму з різних джерел у комплексі та за умов їх різного рівня з органічних джерел на зоотехнічні показники каченят, яких вирощують на м'ясо.

\section{Матеріал і методи досліджень}

Експериментальні дослідження проводились на кафедрі годівлі тварин та технології кормів ім. П.Д. Пшеничного Національного університету біоресурсів і природокористування України. Порівняльний аналіз із метою встановлення оптимального рівня та джерела мікроелементів ( $\mathrm{Mn}, \mathrm{Zn}, \mathrm{Fe}, \mathrm{Cu}$ ) у комбікормі для сільськогосподарської птиці, а саме на каченятах, яких вирощують на м'ясо проведено шляхом постановки науково-господарського досліду. 
Досліди проводили за методом груп-аналогів. Відповідно до схеми досліду (табл. 1) було відібрано 500 добових каченят, з яких за принципом аналогів було сформовано п’ять груп (по три підгрупи): контрольну і чотири дослідних. Птахів однієї групи розміщували у боксах по 10 голів у кожному. При формуванні груп-аналогів враховували масу тіла каченят. Дослід тривав 42 доби і був розділений на два періоди (1-14 та 15-42 доби) та шість підперіодів, кожний 3 яких тривав 7 діб.

Таблиця 1

Схема науково-господарського досліду

\begin{tabular}{|c|c|c|c|c|c|}
\hline \multirow{2}{*}{ Група } & \multirow{2}{*}{ Джерело мікроелементів } & \multicolumn{4}{|c|}{ Додано мікроелемента до раціону, мг/кг } \\
\hline & & $\mathrm{Mn}$ & $\mathrm{Zn}$ & $\mathrm{Fe}$ & $\mathrm{Cu}$ \\
\hline 1 & сульфат & 70 & 80 & 80 & 8 \\
\hline 2 & гліцинат & 70 & 80 & 80 & 8 \\
\hline 3 & цитрат & 70 & 80 & 80 & 8 \\
\hline 4 & гліцинат & 53 & 60 & 60 & 6 \\
\hline 5 & цитрат & 53 & 60 & 60 & 6 \\
\hline
\end{tabular}

Раціон для каченят складався 3 повнораціонного розсипного комбікорму, який містив недостатню кількість Мангану, Цинку, Феруму та Купруму, але відповідав по вмісту енергії та інших поживних речовин нормам, зазначеними у відповідних рекомендаціяx (Rukovodstvo, 2010).

Температура повітря та освітлення приміщення відповідало санітарним нормам, прийнятих у птахівництві. Щільність посадки птахів з розрахунку на одну голову відповідала нормам. Напування відбувалося 3 ніпельних напувалок з розрахунку одна напувалка на 5 птахів. Корм і воду птиця споживала ad libitum.

Упродовж досліду щоденно проводили облік збереженості поголів'я та залишків комбікорму, щотижнево - ваговий ріст птахів та конверсію корму. Масу тіла визначали індивідуальним зважуванням молодняку щотижнево на вагах ВТД-ФД (F998-6ED) 3 точністю до 1 г.

Результати досліджень піддавали звичайним процедурам статистичної обробки даних за допомогою програмного забезпечення MS Excel з застосуванням вбудованих статистичних функцій (СРЗНАЧ, СТАНДОТКЛОН, SEM, ТTЕСТ та ANOVA), аналіз залежностей між досліджуваними факторами та показниками - побудови лінії тренду, визначенням рівняння регресії та коефіцієнту достовірності апроксимації $\left(\mathrm{R}^{2}\right)$. При розрахунку статистичної достовірності враховували, що показник «р» характеризується наступним чином: ${ }^{*} \mathrm{P}<0,05,{ }^{* *} \mathrm{P}<0,01-$ «Виявлено статистично достовірні (значущі) відмінності».

\section{Результати та їх обговорення}

Раціон для каченят складався 3 повнораціонного розсипного комбікорму, який містив недостатню кількість Мангану, Цинку, Феруму та Купруму, але відповідав по вмісту енергії та інших поживних речовин нормам, зазначеними у відповідних рекомендаціях. Склад комбікорму та вміст у ньому енергії та поживних речовин комбікорму представлені у таблиці 2 .

Використання комбікормів відповідно до схеми досліджень позначилося на масі тіла каченят. Так, якщо на початку експерименту вона у птиці піддослідних груп істотно не відрізнялась, то у наступні пері- оди вирощування змінювалася залежно від кормового фактору (табл. 3).

\section{Таблиця 2}

Склад комбікорму та його поживність

\begin{tabular}{lcc}
\hline \multirow{2}{*}{ Склад, \% } & \multicolumn{2}{c}{ Вміст у 100 г } \\
\cline { 2 - 3 } & $1-14$ діб & $15-42$ доби \\
\hline Кукурудза & 52,013 & 58,585 \\
Макуха соєва & 33,848 & 24,578 \\
Шрот соняшниковий & 5,000 & 11,000 \\
Борошно рибне & 5,000 & - \\
Вапняк & 1,139 & 1,836 \\
Премікс ${ }^{1}$ & 3,000 & 4,000 \\
Аналіз & & \\
Обмінна енергія, ккал & 292 & 290 \\
Сирий протеїн & 22,5 & 18,5 \\
Сирий жир & 4,56 & 4,02 \\
Сира клітковина & 4,50 & 5,21 \\
Лізин & 1,35 & 1,00 \\
Метіонін & 0,67 & 0,49 \\
Метіонін + цистин & 0,95 & 0,75 \\
Треонін & 0,90 & 0,75 \\
Триптофан & 0,28 & 0,23 \\
Кальцій & 1,05 & 1,0 \\
Фосфор & 0,82 & 0,65 \\
Фосфор засвоюваний & 0,50 & 0,35 \\
Натрій & 0,20 & 0,18 \\
\hline${ }^{1}$ Премікс містив (у перерахунку на & 1 кг
\end{tabular}
14-добовому віці: $\mathrm{Mn}-100 \mathrm{мг,} \mathrm{Zn}-100 \mathrm{мг,} \mathrm{Fe}-50 \mathrm{мг}, \mathrm{Cu}-15$ мг, $\mathrm{Co}-1$ мг, Se - 0,25 мг, I - 3 мг, Вітамін А - 14 тис. МО, Вітамін Е 100 мг, Вітамін $\mathrm{D}_{3}-3$ тис. МО, Вітамін $\mathrm{K}_{3}-10$ мг, Вітамін $\mathrm{B}_{1}-3$ мг, Вітамін $\mathrm{B}_{2}-12$ мг, Вітамін $\mathrm{B}_{3}-75$ мг, Вітамін $\mathrm{B}_{4}-500$ мг, Вітамін $\mathrm{B}_{5}-16$ мг, Вітамін $\mathrm{B}_{6}-4$ мг, Вітамін $\mathrm{B}_{12}-0,05$ мг, Вітамін $\mathrm{B}_{\mathrm{c}}-$ 2 мг; у 15-42-добовому віці: $\mathrm{Mn}-100$ мг, $\mathrm{Zn}-100$ мг, Fe - 50 мг, $\mathrm{Cu}-15$ мг, $\mathrm{Co}-1,0$ мг, Se - 0,25 мг, I - 3 мг, Вітамін А - 15 тис. МO, Вітамін Е - 100 мг, Вітамін $\mathrm{D}_{3}-4$ тис. МО, Вітамін Е - 5 мг, Вітамін $\mathrm{K}_{3}-5$ мг, Вітамін $\mathrm{B}_{1}-5$ мг, Вітамін $\mathrm{B}_{2}-16$ мг, Вітамін $\mathrm{B}_{3}-$ 50 мг, Вітамін $\mathrm{B}_{4}-500$ мг, Вітамін $\mathrm{B}_{5}-20$ мг, Вітамін $\mathrm{B}_{6}-4$ мг, Вітамін $\mathrm{B}_{12}-0,03$ мг, Вітамін $\mathrm{B}_{\mathrm{c}}-2,5$ мг.

Вірогідна зміна у масі тіла піддослідних каченят була уже відмічена у 7-добовому віці. Так, молодняк, який отримував комбікорм з вмістом $100 \%$ від потреби мікроелементів на основі гліцинатів, істотно переважав за масою тіла каченят контрольної групи на $2,0 \%(\mathrm{P}<0,05)$. 
Таблищя 3

Зміна маси тіла каченят

\begin{tabular}{|c|c|c|c|c|c|c|c|}
\hline \multirow{2}{*}{ Вік, діб } & \multicolumn{5}{|c|}{ Група } & \multirow{2}{*}{ SEM } & \multirow{2}{*}{$\begin{array}{c}\mathrm{P} \\
\text { (ANOVA) }\end{array}$} \\
\hline & 1 & 2 & 3 & 4 & 5 & & \\
\hline 1 & 55,4 & 55,8 & 55,8 & 55,4 & 55,5 & 0,352 & 0,860 \\
\hline 7 & 199,5 & $203,5^{*}$ & 197,6 & 199,7 & 198,1 & 1,312 & 0,017 \\
\hline 14 & 601,8 & 613,1 & 612,9 & 608,2 & 610,2 & 4,375 & 0,353 \\
\hline 21 & 1191,9 & $1217,7^{*}$ & $1213,7^{*}$ & 1209,3 & $1213,8^{*}$ & 7,380 & 0,114 \\
\hline 28 & 1702,0 & $1736,0^{*}$ & $1730,7^{*}$ & 1725,7 & 1724,9 & 9,420 & 0,111 \\
\hline 35 & 2410,7 & $2451,1^{*}$ & $2443,2^{*}$ & 2432,4 & $2443,5^{*}$ & 11,264 & 0,104 \\
\hline 42 & 3109,5 & $3158,9^{*}$ & $3149,5^{*}$ & $3153,2^{*}$ & $3155,8^{*}$ & 13,848 & 0,074 \\
\hline
\end{tabular}

Примітка: ${ }^{\mathrm{P}}<0,05$ по відношенню до першої групи

У 21-добовому віці маса тіла каченят, корм яких містив гліцинати мікроелементів як 100\%, так і 75\% від потреби та комбікорм, який містив цитрати $\mathrm{Mn}$, $\mathrm{Zn}, \mathrm{Fe}, \mathrm{Cu}$, на $1,8-2,2 \%(\mathrm{P}<0,05)$ була більшою за масу птахів контрольної групи. У 28-добовому віці істотну перевагу за масою тіла мали лише каченята, які були забезпечені на 100\% мікроелементами органічної форми, що становило на $1,7-2,0 \%(\mathrm{P}<0,05)$ більше за показники маси тіла каченят, яким згодовували $\mathrm{Mn}, \mathrm{Zn}, \mathrm{Fe}, \mathrm{Cu}$ у формі сульфатів. При визначені маси у 35-добовому віці повторилася така ж сама картина як і у 21-добовому, а саме перевага дослідних груп була на рівні $1,4-1,7 \%(\mathrm{P}<0,05)$.

По закінченню науково-господарського досліду на 42 добу маса каченят усіх дослідних груп вірогідно відрізнялась від маси каченят контрольної групи відповідно на 1,3-1,6\% (P<0,05).

Зробивши статистичний аналіз ANOVA, було встановлено вплив зміни рівня годівлі піддослідних каченят лише у 7-добовому віці $(\mathrm{P}<0,05)$. Різниця між масою птиці у забійному віці була не суттєвою $(\mathrm{P}=0,074)$, але наближалася до порогу вірогідності.
Таким чином, використання комбікорму з вмістом $\mathrm{Mn}, \mathrm{Zn}, \mathrm{Fe}, \mathrm{Cu}$ у вигляді гліцинатів на рівні, який пропонує крос оригінатор, сприяє збільшенню маси тіла порівняно 3 комбікормами, які містили сульфати та цитрати цих мікроелементів. Зниження рівня $\mathrm{Mn}$, $\mathrm{Zn}, \mathrm{Fe}, \mathrm{Cu}$ органічного походження до $75 \%$ від потреби мало позитивний результат по відношенню до контролю, однак каченята цих груп поступилися у масі тіла птахам другої групи.

Відповідно до зміни маси тіла спостерігаються i зміни в абсолютних та середньодобових приростах (табл. 4). Так, абсолютний та середньодобовий приріст був встановлений у каченят, яким у комбікорм вводили мікроелементи у органічній формі, де вони були на $1,3-1,6 \%(\mathrm{P}<0,05)$ більші за контроль, тоді як різниця у прирості між групами за результатами статистичної обробки ANOVA становила вище вірогідного порогу $(\mathrm{P}<0,076)$. Найбільшим абсолютним приростом характеризувалися каченята, яким згодовували мікроелементи у формі гліцинатів у кількості 100\% від потреби.

\section{Таблиця 4}

Показники росту каченят

\begin{tabular}{lccccccc}
\hline \multirow{2}{*}{ Показник } & \multicolumn{5}{c}{ Група } & \multirow{2}{*}{ SEM } & $\begin{array}{c}\text { P } \\
\text { (ANOVA) }\end{array}$ \\
\cline { 2 - 6 } & 1 & 2 & 3 & 4 & 5 & \\
Абсолютний приріст, г & 3054,1 & $3103,2^{*}$ & $3093,7^{*}$ & $3097,9^{*}$ & $3100,3^{*}$ & 13,831 & 0,076 \\
Середньодобовий приріст, г & 72,72 & $73,89^{*}$ & $73,66^{*}$ & $73,76^{*}$ & $73,82^{*}$ & 0,329 & 0,076 \\
Відносний приріст, \% & 192,99 & 193,05 & 193,03 & 193,09 & 193,08 & 0,051 & 0,715 \\
\hline
\end{tabular}

Примітка: "P < 0,05 по відношенню до першої групи

Аналогічно абсолютним приростам, відмічені і зміни у середньодобовому прирості, а от серед показників відносного приросту істотних змін не встановлено.

Для аналізу продуктивності молодняку качок можна віднести й аналіз щодо розподілу їх за масою тіла (рис. 1).

У кінці науково-господарського досліду було розподілено каченят за їх масою тіла. Найменший відсоток каченят масою до 3000 г, був у групі, птиці якої згодовували комбікорм з гліцинатами мікроелементів $(\mathrm{Mn}, \mathrm{Zn}, \mathrm{Fe}, \mathrm{Cu}) 75$ \% від потреби. Ця група містила й найбільшу кількість каченят (54 \%) 3 близькою до середньої по групі масу тіла. Середня ж маса тіла молодняку качок другої групи була найвищою за рахунок маси каченят до 3000 г.
Вплив різного кормового фактора відповідно до схеми досліджень позначився й на конверсії корму для молодняку качок (табл. 5).

За кожен підперіод вирощування конверсія корму змінювалася по групах і залежала від споживання корму та інтенсивності росту каченят. Найвищі витрати кормів на 1 кг приросту маси тіла виявлено у молодняка качок контрольної групи, де вони були на 0,1-1,0\%, вище, ніж каченят інших дослідних груп. Найефективніша конверсія корму у продукцію відмічена у птиці другої групи, якій згодовували комбікорм з вмістом мікроелементів на основі гліцинатів.

Оцінка результатів вирощування молодняку м'ясної птиці за порівнянням споживання корму та його конверсією у продуктивність представлена на рисунку 2. 


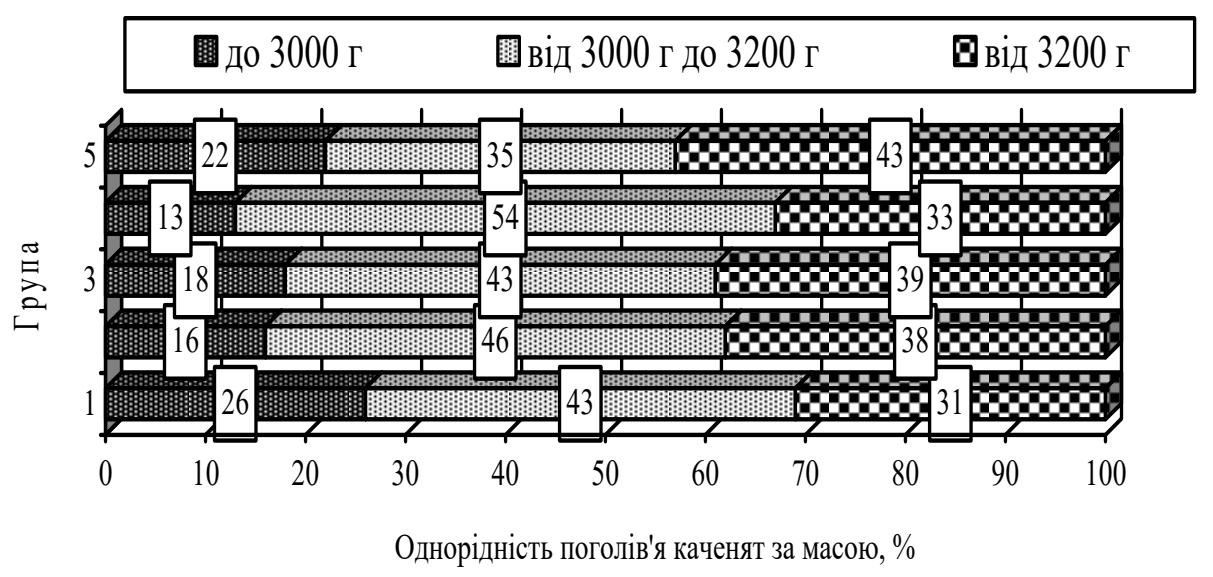

Рис. 1. Розподіл поголів’я каченят за масою тіла

Таблиця 5

Конверсія корму каченятами, кг

\begin{tabular}{cccccc}
\hline \multirow{2}{*}{ Віковий період, діб } & \multicolumn{5}{c}{ Група } \\
\cline { 2 - 6 } & 1 & 2 & 3 & 4 & 5 \\
\hline $1-7$ & 1,306 & 1,289 & 1,288 & 1,315 & 1,300 \\
$8-14$ & 1,249 & 1,241 & 1,242 & 1,249 & 1,242 \\
$15-21$ & 1,667 & 1,635 & 1,638 & 1,644 & 1,646 \\
$22-28$ & 2,205 & 2,189 & 2,189 & 2,200 & 2,210 \\
$29-35$ & 2,261 & 2,243 & 2,255 & 2,263 & 2,271 \\
$36-42$ & 2,499 & 2,485 & 2,497 & 2,480 & 2,497 \\
За період досліду & 2,013 & 1,993 & 1,999 & 2,005 & 2,010 \\
\hline
\end{tabular}

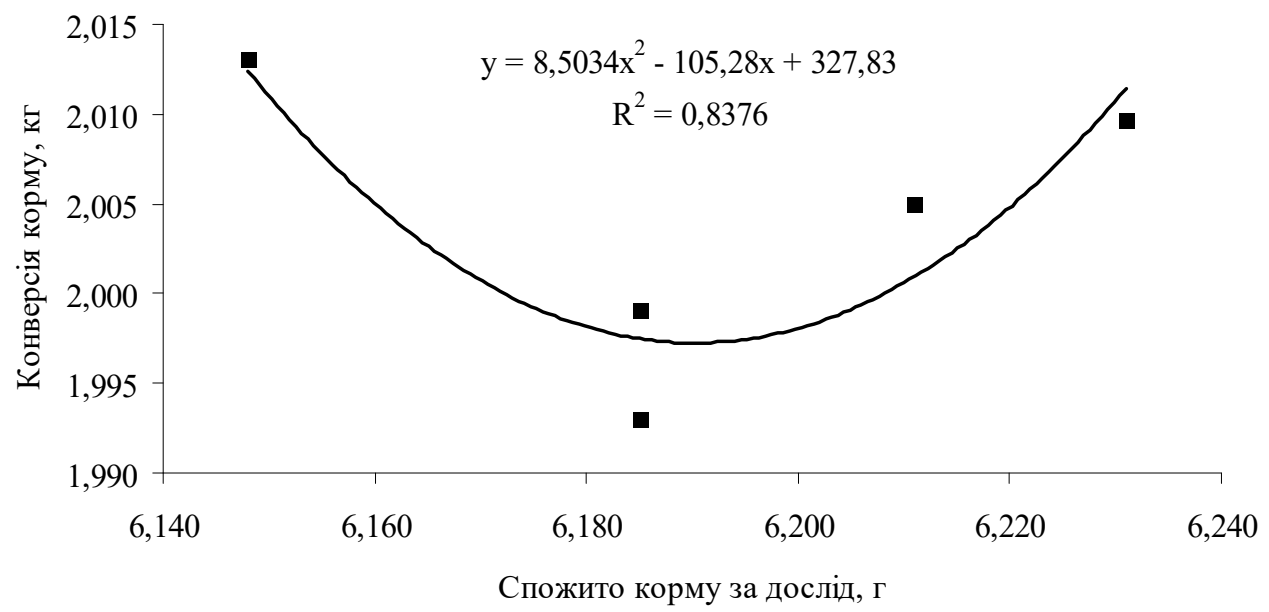

Рис. 2. Залежність конверсії корму від його споживання

Таким чином, експериментально встановлено, що нормування у раціонах каченят, яких вирощують на м'ясо, за такими мікроелементами як $\mathrm{Mn}, \mathrm{Zn}, \mathrm{Fe}, \mathrm{Cu}$ необхідно шляхом додавання їх у вигляді гліцинатів.

\section{Висновки}

Використання у комбікормі для каченят, яких вирощують на м'ясо гліцинатів $\mathrm{Mn}, \mathrm{Zn}, \mathrm{Fe}, \mathrm{Cu}$ порівняно $з$ сульфатами сприяє покращенню їх продуктивних показників.

Маса тіла таких каченят у 42-добовому віці збіль- шується на $1,6 \%$ (Р < 0,05), а конверсія корму у продуктивність на 1,0\% ефективніша.

Використання однофакторного статистичного аналізу було встановлено вплив зміни рівня годівлі піддослідних каченят лише у 7-добовому віці $(\mathrm{P}<0,05)$. Різниця між масою птиці у 42-добовому віці була не суттєвою ( $\mathrm{P}=0,07)$, але наближалася до порогу вірогідності.

Залежність конверсії корму від його споживання за використання різних джерел і рівнів мікроелементів була досить високою $\left(\mathrm{R}^{2}=0,84\right)$, що підтверджує 
зміну продуктивних показників каченят від кормового фактору.

\section{References}

NRC. (1994). Nutrient Requirements of Poultry. 9th rev. ed. Natl. Acad. Press, Washington, DC. doi: 10.17226/2114.

Ibatullin, I.I., Melnik, Ju.F., Otchenashko, V.V., et al. (2015). Praktikum z godivli sil's'kogospodars'kih tvarin: navchal'nij posibnik, K. (in Ukrainian).

Wu, G. (2018). Principles of Animal Nutrition, CRC Press.

Yang, J., Sun, X.X., Li, C.Y., Wu, X.H., \& Yao, J.H. (2011). Effects of copper, iron, zinc, and manganese supplementation in a corn and soybean meal diet on the growth performance, meat quality, and immune responses of broiler chickens. The Journal of Applied Poultry Research, 20 (3), 263-271. doi: 10.3382/japr.2010-00204.

Medvid, S.M., Hunchak, A.V., \& Hmil, E.P. (2018). Histostructure of immunocompetent organs in chicken broilers at the action of aquacrita of micro elements. Scientific Messenger of Lviv National University of Veterinary Medicine and Biotechnologies. 20(83), 44-50. doi: 10.15421/nvlvet8309.
Medvid, S.M., Hunchak, A.V., Gutyj, B.V., \& Ratych, I.B. (2017). Prospects of rational security chickenbroilers with mineral substances. Scientific Messenger of Lviv National University of Veterinary Medicine and Biotechnologies. 19(79), 127-134. doi: 10.15421/nvlvet7925.

Bao, Y.M., Choct, M., Iji, P.A. \& Bruerton, K. (2007). Effect of Organically Complexed Copper, Iron, Manganese, and Zinc on Broiler Performance, Mineral Excretion, and Accumulation in Tissues. The Journal of Applied Poultry Research, 16(3), 448-455. doi: 10.1093/japr/16.3.448.

Abdallah, A.G., El-Husseiny, O.M. \& Abdel-Latif, K.O. (2009). Influence of some dietary organic mineral supplementations on broiler performance. International Journal of Poultry Science. 8(3), 291298. doi: 10.3923/ijps.2009.291.298.

Sirri, F., Maiorano, G., Tavaniello, S., Chen, J., Petracci, M. \& Meluzzi A. (2016). Effect of different levels of dietary zinc, manganese, and copper from organic or inorganic sources on performance, bacterial chondronecrosis, intramuscular collagen characteristics, and occurrence of meat quality defects of broiler chickens. Poultry Science. 95(8), 1813-1824. doi: 10.3382/ps/pew064.

Rukovodstvo po vyrashhivaniju mjasnoj pekisnkoj utki (2010). Rezhim dostupa: http://www.grimaudfreres.com/ en/technical-informations (in Russian). 